\title{
THE NAMES AND SITUATIONS OF THE ORGANS OF THE BODY IN ANIMALS."
}

\author{
BY W. IIUNTING, F.R.C.V.S.
}

(MENBER).

Delivered Nocember Lith, 1900.

Ture Lecturer said that all the structures in the borly that have a function of their own are organs. Thus the skin is an organ of protection, and the bones are organs of support. The chief eliain of bones in the body, called the vertelurae or back bone, is supported by the bones of the limbs. There were flat bones, as in the skull, to protect the brain and certain organs of special sense. The ribs protected the chest, but it was not a solid protection, as between each rib was a partition filled with muscle.

As the lectures were directly in reference to the use of animals for food, it was not necessary to say very mucli about the bones, beciuse there was very little disease in bone which affected the animal for food. There was, howvever, one clisease, of which they had an admirable specimen in the Parkes Muscum, called actinomycosis. As a rule it affected the hearl. Years ago, before the organism which caused this disease was discovered, it used to be classised with cancer, and was probalbly the origin of the notion that eancer is common in the lower animals, which it is not. Most of the bones of the body were separate and joined together by ligraments. With regaird to the joints these would show tolerably well-marked changes if the animal had suffered from such disenses as rheumatism or pyemia. A healthy joint, or a series of healthy joints in an animal, would be almost proof that the animal wis healthy-at any rate it would prove the freedom of the animal from any general emstitutional disease. The french-grey color on the surface of the joints is inlicative of health, anil the presence of a colourless, or nearly colourless fluid in a joint, is natural ; whereas if there were a discoloured joint, and the fluid within

* The lecture was illustrated with numerous diagrams and drawings, together with a number of internal organs of treshly killed animals. 
the joint discolonrerl, then they would regrard that as evidence of it being unlealthy.

Other important organs are the muscles of the body. The muscles are the red flesh. The ordinary individual had an idea that flesh was simply laid on to the bones in irregular masses, perfectly irlespective of action, but observation womld show every portion of flesh hats its own special function to lerform. The muscles are all separate organs, are miule mp of filores, and according to the direction of the filures, so the muscular action takes plivee. Muscle contracts am shortens, thus moving the bones to which it is attached. Not only are there reel muscles, but there are white muscles. The red muscles were the ones under the wovernance of the will, and are known as voluntary muscles, while the white muscular tisites foumb in the hollow organs of the horly and in one or two other places are involmutary in their action. That is to sar, their action went on perfectly indegendently of the will. Such muscular tissues could be foumcl in the intestines and stomachs. One muscle, however, was an excention to the rule, and that was the heart. The heart consisterl of red fleshl, and a rery complicated arrangement of filnes it is. The muscular tissue of the heart is, of conrse, respureel for pumping the blood through the body. That went on whethere the owner liked it or not, and therefore, the heart was in involuntary red muscle. An important muscular organ wats the tongue. Between the tongrue of a horse and the tongue of an ox there was a considerable difference in shape, which rendered it tolerally easy to make sure which was which. The chief peculiarity of the ox's tongue was its long pointed end. The horse's tongue, on the contrary, was long but flattened ont and rouncled at the tip, so that it was easily distinguished from that of the ox. The grallet, or nesophacrus, was in tube which convered the food from the back of the thront down into the stomich. The tongue conveyed the food, after mastication, into the grullet, and as this tube was made up of muscular tissue, partly voluntary aul partly inroluntary, food passed down it without control of the will. It. was possible for an animal to reject a portion of food which had just entered the oesopharens, but it was not possible for the ordinary animal to reject it when it grot a little lower down.

The bodies of animals practically consisted of two large cavities - the chest and the abromen. These two cavities were separated by a curtain or partition, calles the cliaphagm, or by butchers the midriff or skirt. The diaphragm consisted of two parts, the outer or circumferential muscular portion and the central tibrous layer. The muscular portion is attached all round above to the spine, at the sides to the ribs, and beneath 
to the breast bone. It was not quite a perpendicular or a flat curtain. It was placed oblipucly and was concave on its abdominal surface and convex on the surface facing the lungs. When its muscular part contracted, it became nearly flat, and so pushed back the abdominal organs, and drew air into the lungs. It was not only a partition between two cavities, but was the chicf muscle of respiration. It is the muscle which canses hiccongh by its spalsmodic action, and it plays a large part in the action of conghing. Through the diaphragm one or two importint structures passed. There was the nullet carrying food to the stomach. Then from the heart large blood vessels ran back through the diaphragm, and large veins from the hind leugs and back part of the body also passed through the diaphramm.

The chest latd walls partly home-tle ribs-but the abdomen hard wals entirely muscular or filuous. The chest contained the lungs and the leart, two very important organs of the bouly. The cliest was lined thow inhout by a fine membrane called the plenta, which nembrine is reflected over the lungs, so that lowking into the chest of an animal when rlead, they would find it lined ly a cleau gristening membrane. There were some discases which altered the appearance of this membranc very much. In cases of tuberculosis the membrane, which in liealth would be clear and smooth, would be roughened by the growtl upon it of small nolules. As a result of pleurisy, i.e., an inflammation of the pleura, there might be an exudation upon the membrane, or there might be allhesions between the lungs and the pleura. On the healthy specimen before them they would sce this glistening membrane on the surface of the lung. It also formed a partition vertically up and down between the two lungs, so that it divided the chest into two lateral parts, and between them would be found the other vital thoracic orgam, the heart. Between these layers we also find a number of important glimels, the lymplatic gitands of the chest which would be refereed to later on.

The lungs are bi-symmetrical, and in a state of lealth absolutely fill the chest. Immediately air was let in in any quantities into the chest, the lungs collapsed, and the air surrounding them formed a space between the walls of the chest and the lung itself. If the lungs exhibited were inflated they would become nearly twice the size, and when blown up their shape would be more exactly that of the inside of the chest than when in a collapsed condition. The horse's lungs presented in front two anterior lobes or additional pieces. In some lungs there was a more complicated appearance than in others. In the ox's lung, for instance, 
there was a larger number of lobes, three on one side and four on the other, so it could alivays be distinguished fiom that of a horse. There was another difference in the appearance which would enable them to distingruish a horse's lung from an ox's lung. As they knew, the Jungs consisted of a series of air cells. These air cells were in rroups, and the groups or lobules were pressed together and covered by the pleuria. Now if they cut into a loorse's lung they would fincl it fairly homogeneous throughout, and the lobules could not be separated from each other, but if they cut into a bullock's lung they would find the various lobules constituting the lung clearly clefined by the intervening tissue, and if they were torn the lobules could be easily separated from each other. The colour of the lungs was a reddish pink, varying a good deal according to the amount of blood left in the animal. In the carcase of an animal not bled, the lung on the side it laid on after death would alway's be twice as dairk as that on the other side. The lungs were soft and elastic to the touch, but sometimes they got a lung which did not feel soft and elastic. For instance, an animal that had never breathed wonld have solid lungs, and animals that had suffered from inflammation of the lungss of ten had solid partehes in those organs. A portion of healthy lung ought to float in water, a portion of lardened lung, as a result of inflammatory changes, woukl not float in water, nor would the lung of an animal that had never breathed. Among the articles provided for food for liuman beings are calves that lare never breather-some of them, in fact, have never been born, although this is not so common as it used to be. If therefore, they wanted to settle the point of whether an animal had breathed, they had only to get the lung, notice if it sank in water, and they could determine the question. Morbid changes occurreel in the lungs. There were parasitic cliseases, tumours, cysts varying in size from that of a nut to that of an apple. Hardening of portions of the $\operatorname{long}$ resulted from specific disease, and tubercular nodules were common in and on the lung. A contagious disease which used to be common, pleuro-pmeumonia, marked the lungs very clearly. Not only was the part thickened and hardened, but when it was cut into it was mirbled, yellowish stroals, ruming through a firm tissue of different rlegrees of coluur, from pink to red or even to black.

The heart was situated in the chest between the two lungs, and was well protected by the shuulders. It was not on the left sicle, but it was in the centre, and it beats a little more to the left than to the right, therefore, it was felt more to the left than to the right. The heart was contained in a bag known as the pericardium. After death a little fluid would be 
found in this bag, it was more a sort of vapour during the animal's life, aurl facilitated the movement of the heart. The bag of the leart was fixed to the sternum-the breast boneand it wis further held in its place above by the attachment of large blood ressels which ran backwards and forwards and into the lungs. The most marked difference between the heart of a horse and an ox was the fat. Without any other sign they could always tell the difference between a horse's and an ox's heart, because in the ox the fat is hard and firm, whereas in the herse it is soft and greasy, On the surface of the heart of a horse there were two furrows, running down towards the point. In the ox there were three of these furrows. If they wanted further distinctions they could put their fingers into the openings of the blowd vessels, and in the septum which divided the right from the left cavity, they would find a bone in the ox's heirt which is tolerably diagnostic of the animal it belongs to. The ox's heart weighed from $t$ to tilbs. The horse's heart weighed from is to 7lbs., and ran up in the case of large horses to !) or 10llss. or eren more. Attached to the pericardium was one rery large gland, known to butchers as a sweetbread. Where the wind-pipe branches into the bronchi, one for each lung, there is a mass of glands, the bronchial gylands, and underneath on the other surface of the wind-pipe there are another set of glands, the trachial glands. These were important to men who had to inspect food, so their situation should be remembererl.

The abdomen, or cavity behind the diaphranem, contained all the organs concerned in digestion, and in few other organs. The stomach was in all but ruminating animals a singre ol'win, hollow, and bent upon itself something like the shape of a latricot bean. All the abdominal organs were covered, like those in the chest, by a fine membrane, called the peritoneum. $J$ ust as the pleura lined the chest, so the peritoneum lined the abdomen, and was reflecterl over each of the orgins in that civity. If they cut open a stomach or intestine, they would not find a firm laard membrane, but they would find a softer membrane generally covered with mucus; that was the mucous lining of the abdominal organ. The stomach and intestines liat a mucous lining, and they had a museular coat which chalsled the orian to make certain morements. Thuse movements were slow contractions, and were sufficient to carry the foud through one digestive part to the other. In ruminants, the ox and the sheep, there was a set of stomachs unlike what was found in other animals. The food passed down the gullet into the rumen, a large bag in which not a fourth part of digestion takes place. This rumen is known as the paunch 
when dogs are fed on it, but as tripe when men are ferl on it. It was the receptacle for the hurricdly swallowed food, and ruminants could store an enormous quantity there, enough, in fact, to fill a wheelbarrow. When the animal was thoroughly distended, it would lie down or sometimes stand quictly and enjoy the process of rumination. The rumen is tolerably well recognisable out of the body, or even a portion of it, because it had what none of the other stomachs have, large masses of white muscular tissue which form hamls across the stomach, and partially divide it into two different sections, in fact, almost into four. These were muscular bands or contractile organs which enabler the ruminant to force foor from the rumen back into the month. The rumen had a very much smaller bag attached to it called the reticulum, which was callerl so on account of the curious arrangement of its lining membrane. Even a small section of the stomach enabled a man to recognise what it was beciuse the mucous menblane formed a distinct honereomb pattern, the edge of the honeyeomb standing up well above the rest of the membrane. Ruminants hat a third and a fourth stomach. The third stomach is known as the omasum or many plies, its mucous membrane is artistically arranged in a series of parallel folds standing up orer an inch in lecight, and between them was generally foimel a mass of hard food. From this omasum the food prassed into the true digrestive stomach, the stomach which digests the nitrogenous matter; this fourth stomach is called the abomasum or rennet. These first three stomachs of the ox are to be looked upon, not as true digestive stomachs, but as receptacles which prepare the food for digestion in the fourth stomach. From the abomasum, as in other animals, the food passes directly into the intestines.

The intestines consist of two kinds, the small and the large. In such animals as the don and other carnirorous animals, the division into large ant small intestines is, anatomically, more or less imaginary. These animals lave atl almost straight intestine, varying little in calibre. In the lorse and ox the difference between large and small intestine is very apparent. The small intestines of the ox are more conspicuous for their lengrth than anything else; they are twice as long as those in the horse, and stretch to 120 or $140 \mathrm{ft}$. The pig has $72 \mathrm{ft}$. altogether, 56 of which are small intestine; the cat and dog have very short intestines-digestion in the carnivora taking place nearly entirely in the stomach. Animals with large intestines liare a considerable annoment of intestinal digestion, chicfly, of course, of the hydro-carbons of the food.

The liver is situated just at the back of the diaphragm. The horse's liver rests on the left side, and extends on both sides of 
the diaphranm, with a little more on the right, but the ox's liver is almost, entircly on the right side of the diaphragm, because the ruminant, required more room on the left side for the large stomachs. An ox liver weighed about 8 lbs. The colour was dark brown, not varierl, and its surface was smootl, firm to the feel, and homogreneous. Variations in colour would be a little suspicious, but varjations of colour printed to diseases which he did not think would do much harm to ofleer animals consuming them as fool. A cliscoloured liver might he describerl as unmarketable, and the inspector would be yuite justified in preventing its sale if there were eridence of some degeneration or fatty change of the organ. Worse than these were the livers containing spots of different colours, or little tumours varying in size, the solid ones being probably tulserulous in their" mature, and the hollow ones containing fluid being parasitic. The presence of one parasitic cyst in a liver would not wimrant the conclusion that the liver is not healthy; the eyst conld be cut ont and the rest malle rood food. The ox harl a sruluare-shaped liver with a little seprante lobe on its under surface; the liorse had a liver more artistically marle up of three lobes; the pig's liver had tive or six lobes; the sheep's lirer was the same shape as that of the ox. The difference in the number of lobes would enable them to differentinte between a pig's liver and that of a sheep.

The horse biul no gall-bladrler, aurl in that he was absolutely distinet; all solicl-hoofed animals were destitute of a gallblarkler.

The spleen was an organ attached to the stomach, in the ox to the rumen. The horse's spleen was of crescent shape with two points, wicler in the midclle tapering off at both ends. In the ox it was square at the encls, a useful distinction. The spleen was a mottled grey colour, and was made up of a fibrous network containing a julp) it was known to butehers as the milt. In some diseases the spleen was enormously enlarged. During cligestion the spleen of all animals becones distemlerl. It was in organ capable of healthy distention and contraction to its normal size. It was a marked sign of anthrax in the ox when the spleen was ten times its natural size, and very casily broken down with the fiugers, about as dangerous a thing as anyone could do. Before anthrax was diagnoserl as an organismal disease it used to be called splenic fever, and people male these dangerous post mortems with imocence. Gorermment now almost forbacle such post mortems, and specially warned persons that they were not to be made if the operator had a scratch on his hands.

Another gland in the abdomen, the pancreas, was concerned 
in digestion. In the lorse it was just behind the liver, lying across the spine; in the ox it was situated a little lower down in the folds of the mesentery. All the intestines were held together from the spine by folds of the mesentery.

The kicheys were found a little further back still, attached to the spine; in the ox the kidneys were extremely large and tabulated, in other words they are made up of a number of simple kidneys aregrenated together. The kidney of the pig was of squilrer shiape at thic ends. The shape of the lorse's kidneys was different, one kidney being quite a heartshaped object, but the other more the shape of a slieep's kiclney, something of the form of a haricot bean.

Having described the bladder and the uterus, with their disuases, the lecturer turned to the lymplatic glands, which he said were extremely important and very interesting. A large number of these glands were sold as sweetbreads, and it was very necessary to ascertain that there was no clisease about them. He described the chlands in the varions parts of the body, their functions, and appearince. Tuberculosis affected some of the glands more than others, such as the mesenteric, the mammary gland, the throat glands, and the bronchial; and these required careful inspection in the slaughter-house. These lymphatic glands were placed all over the boly, and might be looked upon as sentinels to detect any impurities which inight pass into the system. If therefore they met with suspicious signs in any internal organ, let them examine the nearest lymplartic glind, and if they found it enlarged or changed in colour, or presenting hard nodules or white spots in their centres, they would know discase was present, This was important, because if they had to examine a carcase with all the viscera removed they must cut into the lymphatic gland, and if disease had passed from the internal organs into the tissues it would have infected the glands. If not, they might conclude that that carcase was not infected generally, and was therefore fit for consumption. 